\title{
Disaster risk analysis of Mount Bromo eruption after the 2015 eruption in Sukapura District
}

\author{
Turniningtyas Ayu Rachmawati ${ }^{1, *}$, Dwi Rahmawati $^{2}$, and Arief Rachmansyah $^{3}$ \\ ${ }^{1}$ Department Urban and Regional Planning, Brawijaya University, Jl. MT. Haryono 167, Malang, 65125, Indonesia \\ ${ }^{2}$ Magister Urban and Regional planning, Brawijaya University, J1. MT. Haryono 167, Malang, 65125, Indonesia \\ ${ }^{3}$ Department Civil Engineering, Brawijaya University, Jl. MT. Haryono 167, Malang, 65125, Indonesia
}

\begin{abstract}
Mount Bromo is one of the most active volcanoes in East Java with a 4-5 year interval of the eruption. Its last eruption was in 2015 and is expected to erupt in 2020. The mountain is characterized as having the phreatic type of eruption, which can take months, and made Sukapura district the most seriously affected. Sukapura District is inhabited by Tengger people who strongly uphold their customs. The strong spiritual relationship between Tengger people and Mount Bromo affects the efforts to reduce the disaster risk. In anticipation of the coming eruption in 2020, a disaster risk calculation is required as the basis for disaster risk reduction. This paper examines the risks of Mount Bromo eruption disaster from the aspects of its hazards, vulnerability and community capacity. The results of risk calculation indicate that the vulnerability and capacity are the most influential aspects to the magnitude of the risks suffered by the community. The high-risk areas to prioritize are Ngadisari, Sariwani, Sapikerep, Wonokerto, Ngadirejo, and part of Jetak Village. Moderate risks include part of Kedasih village, part of Pakel Village, part of Ngadas Village, part of Jetak Village and part of Wonokerto Village. The low-risk areas include part of Ngepung Village, Sukapura Village, part of Ngadas Village and part of Wonotoro Village.
\end{abstract}

\section{Introduction}

Mount Bromo is one of five Tengger Mountains, geographically located at 7056 '30 South Latitude and $112037^{\prime}$ East longitude. Administratively located in the Malang, Probolinggo, Lumajang and Pasuruan Regency, Mount Bromo is a volcano with a 4-5 year interval eruption with phreatic or magmatic type eruption stromboli [1]. It last erupted in 2015 and is anticipated to erupt in 2020, based on the eruption pattern period.

Mount Bromo is fascinating for its active crater, a stretch of ocean sand, and exceptionally beautiful sunrise, making it one popular tourist destination for local and foreign tourists. The existence of the attraction leads the community to take the business opportunities by providing accommodation, lodging and culinary. The eruption of Mount Bromo produces volcanic material causing the land temporarily unplanted until the weathering process that makes the land fertile and be able to be planted with various kinds of plants, especially fruits and vegetables. That is why most people around Mount Bromo are farmers and works in the tourism industry.

The eruption of Mount Bromo in 2015 lasted about 3 months, resulting in at least 12,562 and other 473 people suffered from crop failure and significant losses in income from tourism industry respectively with the total loss estimated at 126 billion Rupiahs. The severely damaged areas are Sukapura District, Probolinggo Regency, where 2875 ha of agricultural land was damaged. Jeep, horse, and lodging rental owners were also losing their income up to $90 \%$, if not $100 \%$ [2].

Sukapura district is divided into 12 villages, where 9 villages are mostly Tengger people. For Tengger people, Mount Bromo is a holy mountain. They believe his ancestors have been merged with Mount Bromo. For so long, Mount Bromo make Tengger people feel safe in the environment prone to disaster. They are reluctant to evacuate when the eruption takes place because they do not consider the eruption threatening. As a matter of fact, the eruption is a blessing to be grateful for and welcomed with prayers. It is therefore frequently challenging for the government to disseminate the disaster risk reduction (DRR) as people trust their traditional chairman more than the government in understanding the phenomenon of Mount Bromo eruption.

Reviewing the attitude of the majority of people of Sukapura District to the eruption of Mount Bromo, efforts must be taken to DRR in anticipating the coming 2020 eruption. DRR is a systematic development action and implementation of policies, strategies, and practices to minimize vulnerability, natural hazards as well as eliminate the disastrous impacts of people's livelihoods that fall within the context of sustainable development efforts [3]. DRR policies and strategies have emerged since the $70 \mathrm{~s}[4,5,6,7,8,9]$. These experts focus on DRR by taking into account the broader political, social, environmental, and economic aspects of the disasterrelated context. A review of disaster aspects with a wide range of contexts needs to be done [10]. Therefore DRR

* Corresponding author: t_tyas@ub.ac.id 
strategies as much as possible may include aspects of the hazard itself, vulnerability, and capacity [11].

Based on the concept of DRR that has been described, this paper aims to identify aspects of Mount Bromo eruption disaster hazard, vulnerability and community capacity to the eruption of Mount Bromo before determining DRR measures. The location of the research in Sukapura District is chosen because: 1) it is severely affected by the eruption of 2010 and 2015; 2) it is the main tourist entrance from Probolingo Regency, and 3 ) the custom of the Tengger people that is still strongly believed.

\section{Methodology}

The method used in the study focused on disaster risk analysis using Geographic Information System (GIS) combined with primary data to support comprehensive analysis. The methods include data collection phase, analysis process, until the final result of the assessment of disaster risk area of Mount Bromo eruption in Sukapura District.

\subsection{Hazard assessment}

The natural hazard is a geophysical, atmospheric or hydrological event that has the potential to cause harm or loss [12]. The hazard of the eruption of Mount Bromo is identified through the Map of Disaster Prone Areas issued by PVMBG in 2015. The map shows a volcano prone to the eruption of Mount Bromo and a detailed picture of the impact and potential of pyroclastic flow pathways as well as lava flows and toxic gas discharge sites. The prone to eruption radius map and impact maps are overlaid to produce hazard maps that will be classified into high, moderate and low hazards.

\subsection{Vulnerability assessment}

The vulnerability is a state of being threatened with damage or loss with respect to capacity to anticipate a hazard, overcome hazard, prevent a hazard and recover from disaster hazards [12]. The vulnerability is also called a state of declining resilience due to external influences that threaten life, livelihoods, natural resources, infrastructure, economic productivity and welfare [13]. Vulnerability consists of four components [14]:

1. Physical vulnerability: describes the estimated level of physical (infrastructure) damage when a certain hazard occurs.

2. Economic vulnerability: describes the magnitude of loss or damage to economic activities (economic processes) that occur when there is a danger hazard.

3. Social vulnerability describes an estimate of the extent of vulnerability to life safety in the event of a disaster.

4. Environmental vulnerability: describes the condition of a disaster-prone area that is affected by the geographical and geological conditions of a region.
Vulnerability assessment uses the parameters in Table 1. The level of vulnerability is calculated using index (equation 1). Then each parameter level is specified into three classes: high, moderate and low (Table 1.). The mapping results of each aspect of vulnerability are overlaid by using the "sum weighted overlay" menu in the GIS to obtain the level of vulnerability in Sukapura district.

$S=\frac{\text { average parameter values-minimum parameter values }}{\text { maximum parameter values-minimum parameter values }}$

\subsection{Capacity assesment}

Capacity is assessed by the livelihood asset indicator held by the family in Sukapura District. The livelihood asset variable consists of [15]:

a. Natural Capital is a useful condition for livelihoods that can be viewed from the ease of access to water, forest benefits, and environmental services around the residence [15].

b. Financial Capital. Poor households without financial capital (savings, property, access to credit) can become poorer in the event of a disaster. People with higher economic levels will have lower financial losses than those with low economic levels [16].

c. Social Capital: covers trust, social norms, participation and networks that play a role in disaster recovery. The ownership of social capital shows a significant contribution to the improvement of social conditions, politics, and economic performance. The higher ownership of social capital will form joint actions to achieve common goals in the recovery of disaster impacts, as well as reduce conflicts during the recovery process due to the high level of trust among peers [17].

d. Human Capital is an investment of knowledge and skills or can be in the form of education, training, and health [15]. The higher the level of knowledge (in this case, about disaster) the greater the level of household capacity in facing threatening hazards.

e. Physical capital: is an asset owned by the household and used to maintain life. Physical capital interprets the physical condition of a living environment capable of manifesting the security of a negative impact that threatens a person. Physical conditions usually pay attention to the distance and physical ability of land and buildings.

The calculation of livelihood asset is done to the family sample in Sukapura District. The sampling technique used is a random sampling. The number of samples is calculated by using Isaac and Michael's formula (Equation 2). The result of the sample count is 361 families (KK).

$$
S=\frac{\lambda^{2} \times N \times P \times(1-P)}{\left(d^{2} \times(N-1)\right)+\left(\lambda^{2} \times P \times(1-P)\right)}
$$


Table 1. Vulnerability Assessment Parameter

\begin{tabular}{|c|c|c|c|}
\hline $\begin{array}{c}\text { Vulnera } \\
\text { bility }\end{array}$ & Indicator & Parameter & Classification \\
\hline \multirow{9}{*}{ Physical } & \multirow{3}{*}{$\begin{array}{l}\text { Build up } \\
\text { area }\end{array}$} & $<3,32 \%$ & Low \\
\hline & & $3,32-6,15 \%$ & Moderate \\
\hline & & $>6,15 \%$ & High \\
\hline & \multirow{3}{*}{$\begin{array}{c}\text { House } \\
\text { ownership }\end{array}$} & $<544$ unit & Low \\
\hline & & $\begin{array}{c}544-865 \\
\text { unit }\end{array}$ & Moderate \\
\hline & & $>865$ unit & High \\
\hline & \multirow{3}{*}{$\begin{array}{l}\text { Damaged } \\
\text { roads }\end{array}$} & $0-5,6 \mathrm{~km}$ & Low \\
\hline & & $\begin{array}{c}5,7-11,2 \\
\mathrm{~km}\end{array}$ & Moderate \\
\hline & & $\begin{array}{c}11,3-16,8 \\
\mathrm{~km}\end{array}$ & High \\
\hline \multirow{12}{*}{ Social } & \multirow{3}{*}{$\begin{array}{l}\text { Population } \\
\text { Density }\end{array}$} & $\begin{array}{c}<2 \\
\text { people/ha }\end{array}$ & Low \\
\hline & & $\begin{array}{l}\text { 2-4 people } \\
\text { /ha }\end{array}$ & Moderate \\
\hline & & $\begin{array}{c}>4 \text { people } \\
\text { /ha }\end{array}$ & High \\
\hline & \multirow{3}{*}{$\begin{array}{l}\text { Vulnerable } \\
\text { age }\end{array}$} & $\begin{array}{c}<317 \\
\text { people }\end{array}$ & Low \\
\hline & & $\begin{array}{c}317-532 \\
\text { people }\end{array}$ & Moderate \\
\hline & & $\begin{array}{c}>532 \\
\text { people }\end{array}$ & High \\
\hline & \multirow{3}{*}{ Growth rate } & $<(-1) \%$ & Low \\
\hline & & $(-1)-2 \%$ & Moderate \\
\hline & & $>2 \%$ & High \\
\hline & \multirow{3}{*}{$\begin{array}{l}\text { Number of } \\
\text { Low } \\
\text { Education }\end{array}$} & $\begin{array}{l}81-260 \\
\text { people }\end{array}$ & Low \\
\hline & & $\begin{array}{c}261-438 \\
\text { people }\end{array}$ & Moderate \\
\hline & & $\begin{array}{c}439-617 \\
\text { people }\end{array}$ & High \\
\hline \multirow{9}{*}{ Economy } & \multirow{3}{*}{$\begin{array}{l}\text { Vulnerable } \\
\text { Household }\end{array}$} & $<75 \%$ & Low \\
\hline & & $75-86 \%$ & Moderate \\
\hline & & $>86 \%$ & High \\
\hline & \multirow{3}{*}{$\begin{array}{l}\text { Poverty } \\
\text { ratio }\end{array}$} & $<26 \%$ & Low \\
\hline & & $26-43 \%$ & Moderate \\
\hline & & $>43 \%$ & High \\
\hline & \multirow{3}{*}{$\begin{array}{l}\text { Land area } \\
\text { productive }\end{array}$} & $<40 \%$ & Low \\
\hline & & $40-61 \%$ & Moderate \\
\hline & & $>61 \%$ & High \\
\hline \multirow{9}{*}{$\begin{array}{c}\text { Environ } \\
\text { ment }\end{array}$} & \multirow{3}{*}{$\begin{array}{l}\text { Protected } \\
\text { and } \\
\text { production } \\
\text { forest area }\end{array}$} & $<31 \%$ & Low \\
\hline & & $31-62 \%$ & Moderate \\
\hline & & $>62 \%$ & High \\
\hline & \multirow{3}{*}{$\begin{array}{c}\text { Conservatio } \\
n \text { area of } \\
\text { TNBTS }\end{array}$} & $<23 \%$ & Low \\
\hline & & $23-46 \%$ & Moderate \\
\hline & & $46-69 \%$ & High \\
\hline & \multirow{3}{*}{ Shrub area } & $<10 \%$ & Low \\
\hline & & $10-19 \%$ & Moderate \\
\hline & & $>19 \%$ & High \\
\hline
\end{tabular}

\section{Explanation:}

$\mathrm{S} \quad$ : number of samples.

$\mathrm{N}$ : number of families

$\lambda \quad: \lambda^{2}=3.841$ for trust level 0.95

$\mathrm{P} \quad$ : population proportion $(\mathrm{P}=0.5)$

d : Accuracy degree, reflected by tolerable inaccuracy $(0.05)$

$$
\begin{gathered}
S=\frac{3,841 \times 5.919 \times 0,5 \times(1-0,5)}{\left((0,05)^{2} \times(5.919-1)\right)+(3,841 \times 0,5 \times(1-0,5))} \\
S=\frac{3,841 \times 5.919 \times 0,5 \times 0,5}{(0,0025 \times 5918)+(3,841 \times 0,5 \times 0,5)} \\
S=\frac{5.683,48}{14,79+0,96}=\frac{5.683,48}{15,75}=360,75 \approx 361 \text { responden }
\end{gathered}
$$

The stages of livelihood asset calculation are as follows:

1. Calculating the average answer questionnaire respondents.

2. Calculating the index of the average value of the answer (Equation 3) if the optimization direction (Table 2.) is maximized $(+)$, and Equation 4 if the optimization direction is minimal (-).

$$
\begin{aligned}
& S=\frac{\text { Average assesment of respondent-Minimum value }}{\text { Maximum value-Minimum value }} \\
& S=\frac{\text { Average assesment of respondent-Maximum value }}{\text { Minimum value-Maximum value }}
\end{aligned}
$$

3. Calculating capital ownership, calculating the average index of each capital parameter.

4. Categorizing each capital index (Table 2.).

5. Creating a pentagon (Fig. 1.) with a maximum radius of 3 (three) unit.

6. Calculating the area of the Pentagon (Equation 5). The maximum area of the Pentagon is 2.38 units $^{2}$ and the minimum area is 0 units $^{2}$. The area is classified into three classes that reflect the capacity level.

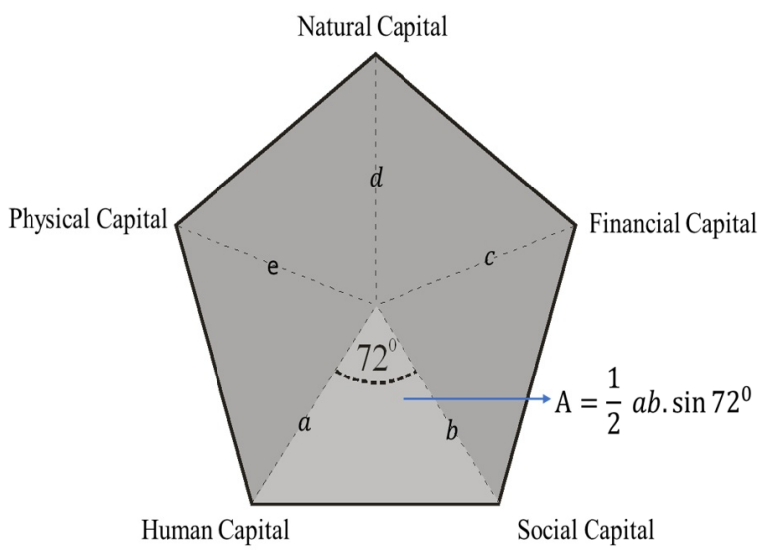

Fig. 1. Pentagon Asset

\subsection{Disaster risk assessment and disaster risk reduction}

Risk assessment according to Perka BNPB No. 2 of 2012 on General Guidelines for Assessing Disaster Risk is determined by Equation 6. The approach shows the relationship between hazard, vulnerabilities, and capacities. The higher the level of hazard and vulnerability in a region, the higher the risk level of the region, while the higher the capacity in dealing with disasters in a region, the lower the risk level in a region. Operationalization of Equation 6 is done by overlaying the hazard-vulnerability map (Table 4), as well as determining the level of risk (Table 5).

$$
\begin{aligned}
& L_{\text {pentagon }}=\left(\frac{1}{2} a b \cdot \sin 72^{0}\right)+\left(\frac{1}{2} b c \cdot \sin 72^{0}\right)+\left(\frac{1}{2} c d \cdot \sin 72^{0}\right)+ \\
& \left(\frac{1}{2} d e \cdot \sin 72^{0}\right)+\left(\frac{1}{2} e a \cdot \sin 72^{0}\right)
\end{aligned}
$$


Table 2. Capacity Assessment Parameter

\begin{tabular}{|c|c|c|}
\hline $\begin{array}{c}\text { Sub } \\
\text { Variable }\end{array}$ & Parameters & $\begin{array}{c}\text { The direction } \\
\text { of } \\
\text { Optimization } \\
*\end{array}$ \\
\hline \multirow{3}{*}{$\begin{array}{l}\text { Natural } \\
\text { Capital }\end{array}$} & $\begin{array}{l}\text { The benefits of Mount } \\
\text { Bromo }\end{array}$ & + \\
\hline & The benefits forest & + \\
\hline & Access to clean water & + \\
\hline \multirow{6}{*}{$\begin{array}{c}\text { Financial } \\
\text { Capital }\end{array}$} & Income & + \\
\hline & Savings & + \\
\hline & Livestock & + \\
\hline & Vehicles ownership & + \\
\hline & Area of fields & + \\
\hline & $\begin{array}{l}\text { Ease of getting } \\
\text { business credit }\end{array}$ & + \\
\hline \multirow{3}{*}{$\begin{array}{l}\text { Social } \\
\text { Capital }\end{array}$} & $\begin{array}{c}\text { The intensity of } \\
\text { meeting of the society }\end{array}$ & + \\
\hline & $\begin{array}{l}\text { Level of familiarity } \\
\text { with the neighboring }\end{array}$ & + \\
\hline & $\begin{array}{c}\text { Involvement in } \\
\text { disaster organization }\end{array}$ & + \\
\hline \multirow{3}{*}{$\begin{array}{l}\text { Human } \\
\text { Capital }\end{array}$} & $\begin{array}{l}\text { Knowledge of } \\
\text { eruption signs }\end{array}$ & + \\
\hline & $\begin{array}{c}\text { Knowledge of } \\
\text { Disaster Prone Areas } \\
\text { of Mount Bromo } \\
\text { eruption }\end{array}$ & + \\
\hline & $\begin{array}{c}\text { Involvement in } \\
\text { environmental } \\
\text { conservation }\end{array}$ & + \\
\hline \multirow{3}{*}{$\begin{array}{l}\text { Physical } \\
\text { Capital }\end{array}$} & $\begin{array}{l}\text { Recovery process } \\
\text { duration (month) of } \\
\text { the agricultural land } \\
\text { after the eruption of } \\
\text { Mount Bromo }\end{array}$ & - \\
\hline & $\begin{array}{l}\text { Distance to the health } \\
\text { facilities }(\mathrm{km})\end{array}$ & + \\
\hline & $\begin{array}{l}\text { Distance from house } \\
\text { to a river }(\mathrm{m})\end{array}$ & - \\
\hline
\end{tabular}

Table 3. Index And Pentagon Area Classification

\begin{tabular}{|c|c|c|c|}
\hline \multirow{2}{*}{$\begin{array}{c}\text { Category } \\
\text { Basis }\end{array}$} & \multicolumn{3}{|c|}{ Level } \\
\hline & Low & Moderate & Low \\
\hline $\begin{array}{l}\text { Natural } \\
\text { Capital } \\
\text { Index }\end{array}$ & $0,30-0,50$ & $0,51-0,69$ & $0,70-0,88$ \\
\hline $\begin{array}{c}\text { Financial } \\
\text { Capital } \\
\text { Index }\end{array}$ & $0,15-0,31$ & $0,32-0,48$ & $0,49-0,65$ \\
\hline $\begin{array}{c}\text { Social } \\
\text { Capital } \\
\text { Index }\end{array}$ & $0,20-0,37$ & $0,37-0,54$ & $0,54-0,71$ \\
\hline $\begin{array}{c}\text { Human } \\
\text { Capital } \\
\text { Index }\end{array}$ & $0,09-0,38$ & $0,39-0,68$ & $0,68-0,98$ \\
\hline $\begin{array}{l}\text { Physical } \\
\text { Capital } \\
\text { Index }\end{array}$ & $0,13-0,39$ & $0,40-0,66$ & $0,67-0,92$ \\
\hline $\begin{array}{c}\text { Pentagon } \\
\text { Area (unit }{ }^{2} \text { ) }\end{array}$ & $0,48-7,45$ & $7,46-14,42$ & $14,43-21,40$ \\
\hline
\end{tabular}

Disaster Risk $\approx$ Hazards $* \frac{\text { Vulnerability }}{\text { Capacity }}$
Table 4. Hazard-Vulnerability Overlay Matrix

\begin{tabular}{|c|c|c|c|}
\hline Hazards & High & Moderate & Low \\
Vulnerabilities & & & \\
\hline Low & Moderate & Low & Low \\
\hline Moderate & High & Moderate & Low \\
\hline High & High & High & Moderate \\
\hline
\end{tabular}

Source: [18]

Table 5. Risk Matrix

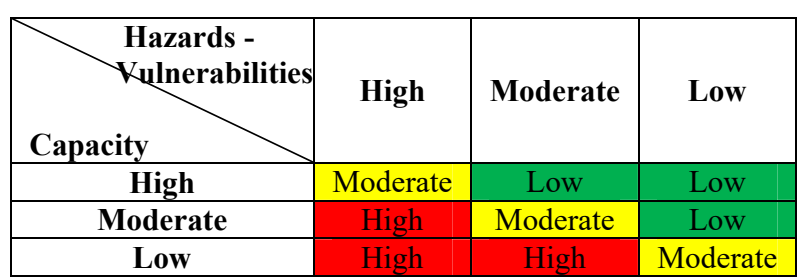

Source: [18]

\section{Result And discussion}

\subsection{Disaster risk assessment}

Mount Bromo Eruption Hazard

The radius prone to the eruption of Mount Bromo eruption set PVMBG 2015 into three typologies (KRB I, KRB II and KRB III):

a. KRB III: is a high-impact area of volcanic eruption and located at a radius of $0-5 \mathrm{~km}$ from the eruption center (Table 6). The high impact areas of Mount Bromo eruption are Ngadisari, Sariwani, Wonokerto, Ngadirejo, Ngadas, Jetak and Wonotoro villages. The majority area of Sukapura District belongs to KRB III $(41 \%)$ because most of the area is within a radius of $0-5 \mathrm{~km}$ from the crater.

b. KRB II: is a moderate-impact area, potentially throwing (incandescent) stones, lava flows, and toxic gases. KRB II is at the radius of $5-10 \mathrm{~km}$ from the crater, covering Sariwani, Sapikerep, Wonokerto, Ngadirejo, Ngadas, and Jetak villages (24\% of Sukapura District).

c. KRB I: is a low-impact area, yet is exposed to heavy ash rain and possibly throwing (incandescent) stones. Radius KRB I is $10-15 \mathrm{~km}$ from the crater. The areas that include KRB I are Sariwani, Kedasih, Pakel, Ngepung, Sukapura, and Sapikerep Villages (31\% of Sukapura District).

The impact of Mount Bromo eruption in Sukapura District is classified as high, moderate and low impact area. The high-impact areas are potentially exposed to the incandescent material, hot lava flows, heavy ash rains and toxic gas streams. High impact category villages include Ngadisari, Ngadirejo and Ngadas Villages. The two villages are the priority of DRR eruption of Mount Bromo by BPBD Probolinggo Regency. Refugee posts and aid priorities are always directed at the two villages in the event of an eruption.

Map of KRB eruption of Mount Bromo and impact of eruption is overlaid to get the Mount Bromo eruption 
hazard map (Fig. 2.). Fig. 2. and Table 6. show that the majority of Sukapura Districts were delineated as high hazard areas (5936.18 ha) covering nine villages: Ngadisari, Sariwani, Sukapura, Sapikerep, Wonotoro, Ngadirejo, Ngadas, Jetak and Wonotoro villages. The majority of people in high hazard areas still firmly believe that Mount Bromo eruption is not a lifethreatening, even when the eruption occurs, people still do their daily and ceremonial activities.

Table 6. Bromo Mountain Eruption Hazard Area Of 9 Villages In Sukapura District

\begin{tabular}{|c|c|c|c|c|}
\hline \multirow{2}{*}{ Villages } & \multicolumn{3}{|c|}{ Hazard Level (ha) } & \multirow{2}{*}{$\begin{array}{l}\text { Total } \\
\text { Area } \\
\text { (ha) }\end{array}$} \\
\hline & Low & Moderate & High & \\
\hline Ngadisari & - & - & 1036,39 & 1036,39 \\
\hline Sariwani & 505,12 & 661,13 & 1172,96 & 2339,21 \\
\hline Kedasih & 894,87 & - & - & 894,87 \\
\hline Pakel & 608,37 & - & - & 608,37 \\
\hline Ngepung & 443,86 & - & - & 443,86 \\
\hline Sukapura & - & - & 807,99 & 807,99 \\
\hline Sapikerep & 0,07 & 977,81 & 350,46 & 1328,34 \\
\hline Wonokerto & - & 485,35 & 1,58 & 486,93 \\
\hline Ngadirejo & - & 246,98 & 1238,99 & 1485,97 \\
\hline Ngadas & - & 144,7 & 971,24 & 1115,94 \\
\hline Jetak & - & 144,08 & 112,72 & 256,8 \\
\hline Wonotoro & - & 159,13 & 233,85 & 392,98 \\
\hline Total & 2452,29 & 2819,18 & 5926,18 & 11197,65 \\
\hline
\end{tabular}

Source: Assessment with vector data, 2018

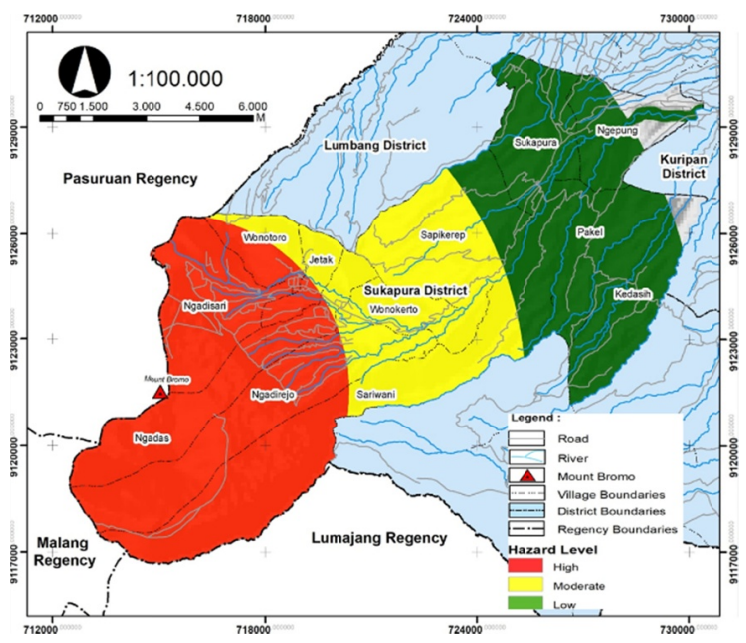

Fig. 2. Bromo Mountain Eruption Hazard of Sukapora District

\subsection{Vulnerability to Mount Bromo eruption}

Sukapura District is categorized as having low physical vulnerability thanks to the little-built land area and good condition infrastructures and roads. Villages with low physical vulnerabilities are Ngadisari, Ngepung, Wonokerto, Ngadas, Jetak, and Wonotoro villages. Sukapura Village is regarded as having high-physical vulnerability because it is the main entrance of tourists from Probolinggo Regency, which has many supporting tourism facilities and infrastructures such as hotels, inns, restaurants, souvenir shops and others.
Economically, villages in Sukapura District are classified as having a moderate economic vulnerability. But Ngadirejo and Kedasih Villages have high economic vulnerabilities, as the majority of the people work in agriculture and tourism sectors that are very vulnerable to the eruption of Mount Bromo. Farmers suffer from crop failure and some cannot run their tourism business. On the other hand, the two villages have a higher number of poverty than do the other villages.

Socially, Sukapura District is dominated by low vulnerability level. The high social vulnerability is found in Sukapura Village because it has a high population density, high vulnerability, and high population growth. The level of vulnerability is present in five villages: Sariwani, Kedasih, Pakel, Ngepung, and Sapikerep Villages.

Mount Bromo and its surroundings (including part of Sukapura District) is a conservation area of Bromo Tengger Semeru National Park (TNBTS). In addition, Sukapura District also has forest and shrub areas vulnerable to burning due to the throwing of Mount Bromo eruption incandescent materials. Therefore, villages in Sukapura District have environmental vulnerabilities that are mostly moderate and some are low.

The four aspects of vulnerability have been identified and mapped. Furthermore, the four maps are covered so that the vulnerability map of Sukapura District (Fig. 3.) and its vulnerability index (Table 7.) are obtained. There are six villages with a high level of vulnerability: Sariwani, Kedasih, Pakel, Sukapura, Sapikerep, and Ngadirejo. Those villages are vulnerable due to such factors as high economic vulnerability aspect (Kedasih and Ngadirejo); high physical and social vulnerability (Sukapura); moderate physical, economic and social vulnerabilities (Sapikerep), moderate physical, economic, social and environmental vulnerabilities (Sariwani and Pakel).

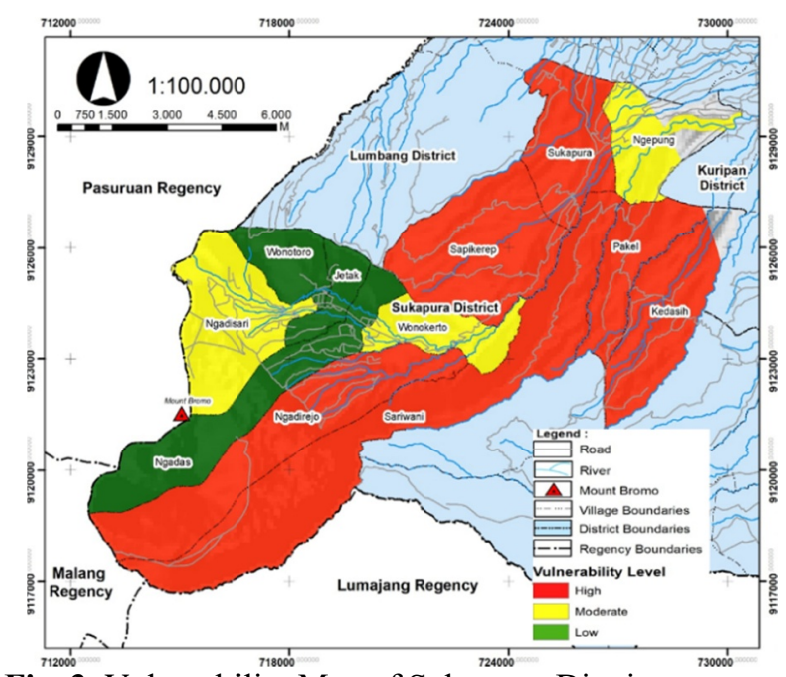

Fig. 3. Vulnerability Map of Sukapura District to Bromo Mountain Eruption 
Table 7. The Vulnerability to Bromo Mountain Eruption

\begin{tabular}{|c|c|c|c|c|c|c|c|c|c|c|}
\hline \multirow{3}{*}{$\begin{array}{c}\text { Villages } \\
\text { Ngadisari }\end{array}$} & \multicolumn{8}{|c|}{ Vulnerability Index and the Categories } & \multirow{3}{*}{$\begin{array}{c}\begin{array}{c}\text { Overlay } \\
\text { result } \\
\text { index }\end{array} \\
0,33\end{array}$} & \multirow{3}{*}{$\begin{array}{c}\begin{array}{c}\text { Vulnerability } \\
\text { level } \\
\text { categorization }\end{array} \\
\text { Moderate }\end{array}$} \\
\hline & \multicolumn{2}{|c|}{$\begin{array}{c}\text { Physical } \\
\text { Vulnerability }\end{array}$} & \multicolumn{2}{|c|}{$\begin{array}{c}\text { Economic } \\
\text { Vulnerability }\end{array}$} & \multicolumn{2}{|c|}{$\begin{array}{c}\text { Social } \\
\text { Vulnerability }\end{array}$} & \multicolumn{2}{|c|}{$\begin{array}{l}\text { Environment } \\
\text { Vulnerability }\end{array}$} & & \\
\hline & 0,23 & Low & 0,53 & moderate & 0,20 & low & 0,35 & Moderate & & \\
\hline Sariwani & 0,43 & Moderate & 0,55 & moderate & 0,35 & moderate & 0,42 & Moderate & 0,44 & High \\
\hline Kedasih & 0,39 & Moderate & 0,70 & high & 0,52 & moderate & 0,35 & Moderate & 0,49 & High \\
\hline Pakel & 0,38 & Moderate & 0,66 & moderate & 0,63 & moderate & 0,39 & Moderate & 0,52 & High \\
\hline Ngepung & 0,24 & Low & 0,47 & moderate & 0,37 & moderate & 0,23 & Low & 0,33 & Moderate \\
\hline Sukapura & 0,69 & High & 0,25 & low & 0,81 & high & 0,21 & Low & 0,49 & High \\
\hline Sapikerep & 0,54 & Moderate & 0,64 & moderate & 0,40 & moderate & 0,31 & Low & 0,47 & High \\
\hline Wonokerto & 0,24 & Low & 0,56 & moderate & 0,33 & Low & 0,32 & Low & 0,36 & Moderate \\
\hline Ngadirejo & 0,41 & Moderate & 0,72 & high & 0,24 & Low & 0,33 & Low & 0,42 & High \\
\hline Ngadas & 0,01 & Low & 0,34 & moderate & 0,16 & Low & 0,37 & Moderate & 0,22 & Low \\
\hline Jetak & 0,09 & Low & 0,66 & moderate & 0,22 & Low & 0,17 & Low & 0,28 & Low \\
\hline Wonotoro & 0,05 & Low & 0,46 & moderate & 0,11 & Low & 0,43 & Moderate & 0,26 & Low \\
\hline
\end{tabular}

\subsection{Community Capacity to Mount Bromo Eruption}

Community capacity is calculated based on parameters (Table 2.) through the livelihood asset assessment stage. The result of the identification of natural capital aspect shows Ngadisari, Ngadas, Jetak, and Wonotoro Villages are amongst the high level. According to Minister of Forestry Decree No.SK. 178 / Menhut-II / 2005 on the determination of Bromo Tengger Semeru National Park area (TNBTS), the management of TNBTS is grouped into the core zone, jungle zone, and utilization zone. Although the management of Bromo Mountain Nature tourism is under the authority of TNBTS management, the community can still support and contribute tourism activities in term of providing such services as accommodation, horse rentals, climbing equipment and so forth, thus, many people in the area work in the tourism sector. Mount Bromo is advantageous for people in Ngadisari, Ngadas Jetak, and Wonotoro Villages. Those in the four villages also consider clean water accessible and consider the surrounding forests to provide benefits as a source of wood for fuel and various plants that grow to be consumed preserving its sustainability.

From the recapitulation result of the questionnaire and calculation of the index of social capital parameters it reveals that there are two villages with high social capital: Kedasih and Ngadas, thanks to the routine community meetings held one to eight times monthly. Mostly, the meetings discuss the efforts to overcome the eruption of Mount Bromo disaster effects and are to socialize the village, district and regency government plans for the efforts. Ngadas village has high social capital because of the high number of people who participate actively in DRR organizations recognized as
"Bromo Lovers." In addition, the two villages with high social capital strongly uphold the familiarity with their neighbors, they even are still familiar with both fellow communities despite their distant homes. Such closeness develops a sense of solidarity and harmony that leads to a conducive atmosphere in case of an emergency situation.

Financially, there are three villages with high financial capital: Ngadisari, Pakel and Wonokerto, thanks to their high income when compared to other villages. Having high revenues, which are classified as moderate to high, enables them to have more savings. Land ownership is relatively higher than those of other villages, with the average 1-4 ha of land every household. Easy access to loans is advantageous for the community as they can get loans from banks and cooperatives as well as loans from family or relatives. Motor vehicles they have supported their daily activities and business such as motorcycle taxi and accommodation, as well as transporting crops. In addition, livestock ownership such as goats, cows, and horses are also availed when the eruption occurs, because they can easily sell them.

The calculation of ownership of human capital shows only Ngadas Village and Wonotoro Village that have high human capital. Communities in the two villages are more aware of the sign of the eruption and actively involved in environmental conservation compared to those in other villages. Tengger people's belief to provide offerings for nature to make the community (especially those in Ngadas and Wonotoro Villages) conserve nature needs to be taken into account. There is no parameter of knowledge about whether they live in the disaster-prone area. The majority of people in Sukapura District do not understand the position of their residence on KRB of Mount Bromo, made by the government, but they realize the level of the 
vulnerability of their area, based on the long history former experiences and stories of older generations.

From the calculation of physical capital, villages in Sukapura District generally have low and moderate physical capital, only one with high physical capital: Sukapura Village. The advantages of having physical capital parameters for Sukapura Village compared to other villages are the speedy field function recovery and the short distance and easy access to health facilities. Sukapura village is located at a radius of $10-15 \mathrm{~km}$ from the crater of Mount Bromo, so the direct impact on the field is not significant, thus it has a high index for the recovery duration of the field. As the center of Sukapura District, it is not surprising that infrastructure facilities including health facilities in Sukapura Village outnumber those in other villages, with access closer $(<1$ $\mathrm{km})$. In addition to the two aspects, the distance of the community home from the river where the lava flow is also rather distant $(>150 \mathrm{~m})$ so there is no cold lava flowing to the settlements.

From the categorization of each aspect of capital ownership, it can be drawn the Pentagon asset villages in Sukapura District in Fig. 4. The Pentagon asset area of each village is calculated by equation 5 to obtain the results listed in Table 8. The classification of pentagon area based on Table 3 obtains the level of community capacity villages in Sukapura District. The villages with moderate capacity are Ngadas, Ngadirejo, Kedasih, Ngadisari, Pakel, Sukapura and Wonotoro Villages, and the other is low capacity.

\subsection{Disaster risk of mount bromo eruption in sukapura district}

The Mount Bromo eruption risk is obtained from the overlay stage of Fig. 2. and Fig. 3. based on Table 4 . matrix. The overlay results are overlaid with a capacity map of Fig. 5. based on Table 5. resulting in the delineation of the Mount Bromo eruption risk level (map Fig. 6.). The majority areas of Sukapura District are classified as high risk (6799,55 ha) including Ngadisari Village, Sariwani Village, Sapikerep Village, Wonokerto Village, Ngadirejo Village and Jetak Village (Table 9.).

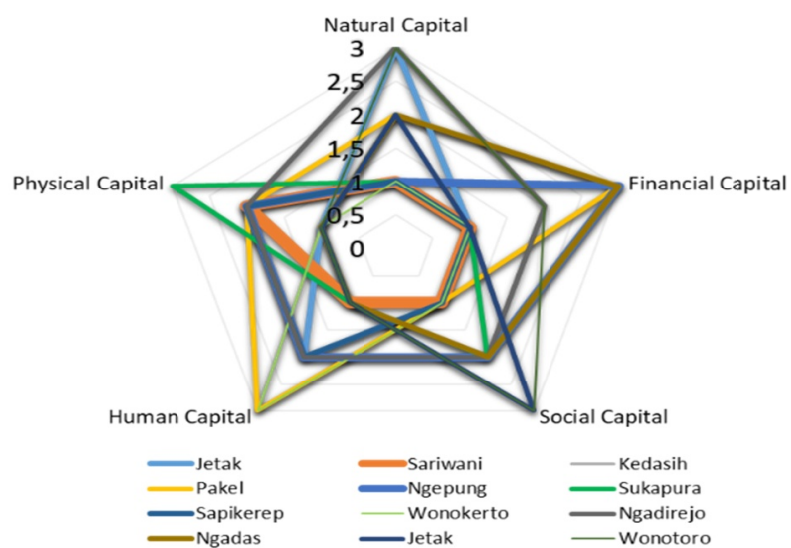

Fig. 4. Pentagon Asset of 9 Villages in Sukapura District

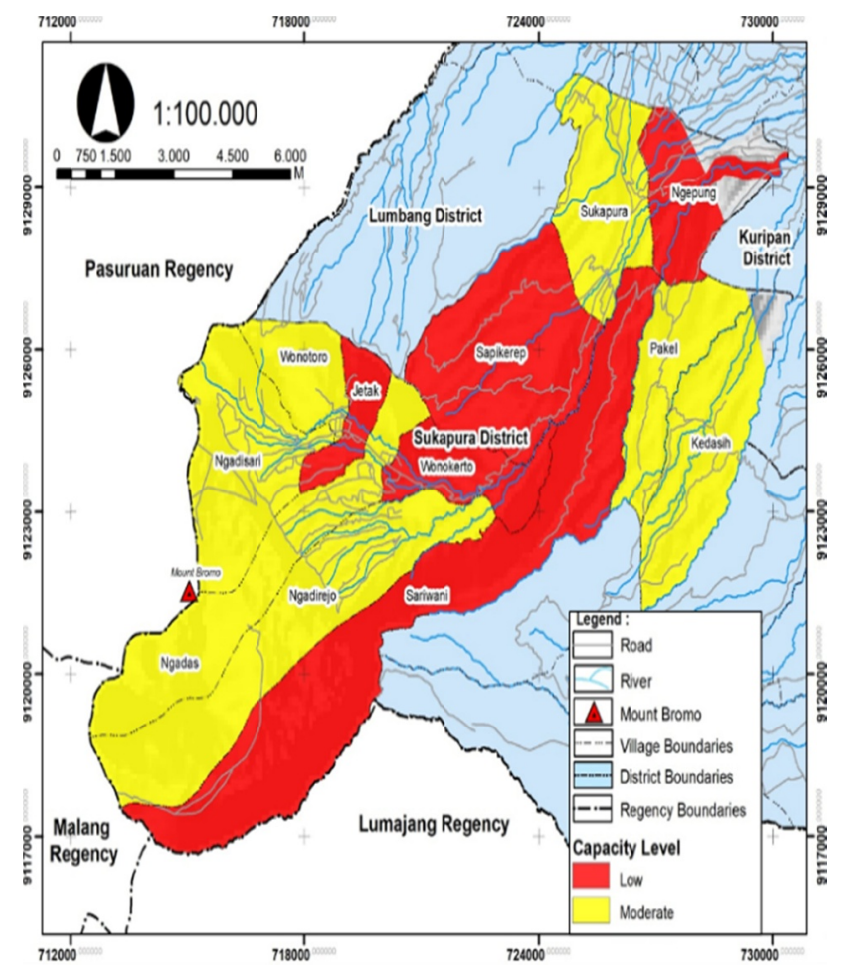

Fig. 5. Capacity Map of the Villages in Sukapura District

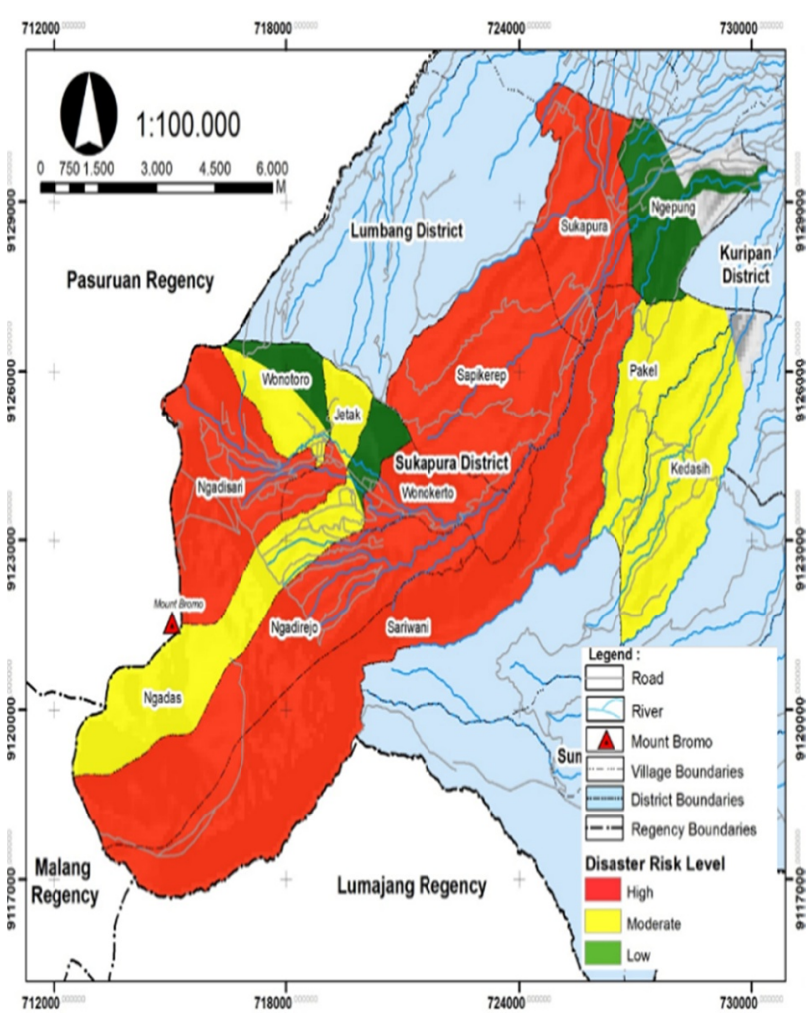

Fig. 6. Mount Bromo Eruption Disaster Risk Map of Villages in Sukapura District 
Table 8. The capacity to Bromo mountain eruption

\begin{tabular}{|c|c|c|c|c|c|c|c|c|c|c|c|c|}
\hline \multirow{3}{*}{$\begin{array}{c}\text { Villages } \\
\text { Jetak }\end{array}$} & \multicolumn{10}{|c|}{ Capital Index and its level } & \multirow{3}{*}{$\begin{array}{c}\begin{array}{c}\text { Pentag } \\
\text { on } \\
\text { Area }\end{array} \\
5,23 \\
\end{array}$} & \multirow{3}{*}{$\begin{array}{c}\begin{array}{c}\text { Capacity } \\
\text { Level }\end{array} \\
\text { Low }\end{array}$} \\
\hline & \multicolumn{2}{|c|}{ Nature Capital } & \multicolumn{2}{|c|}{ Social Capital } & \multicolumn{2}{|c|}{ Financial Capital } & \multicolumn{2}{|c|}{ Human Capital } & \multicolumn{2}{|c|}{ Physical Capital } & & \\
\hline & 0,88 & High & 0,36 & Low & 0,16 & Low & 0,66 & Moderate & 0,33 & Low & & \\
\hline Kedasih & 0,42 & Low & 0,70 & High & 0,48 & Moderate & 0,41 & Moderate & 0,31 & Low & 8,08 & Moderate \\
\hline Ngadas & 0,75 & High & 0,71 & High & 0,23 & Low & 0,72 & High & 0,29 & Low & 9,99 & Moderate \\
\hline Ngadirejo & 0,63 & Moderate & 0,41 & $\begin{array}{c}\text { Modera } \\
\text { te }\end{array}$ & 0,45 & Low & 0,67 & Moderate & 0,55 & Moderate & 7,61 & Moderate \\
\hline Ngadisari & 0,88 & High & 0,40 & $\begin{array}{c}\text { Modera } \\
\text { te }\end{array}$ & 0,65 & High & 0,55 & Moderate & 0,41 & Moderate & 13,79 & Moderate \\
\hline Ngepung & 0,63 & Moderate & 0,34 & Low & 0,29 & Low & 0,20 & Low & 0,41 & Moderate & 4,76 & Low \\
\hline Pakel & 0,40 & Low & 0,64 & High & 0,51 & High & 0,41 & Moderate & 0,47 & Moderate & 11,41 & Moderate \\
\hline Sapikerep & 0,30 & Low & 0,24 & Low & 0,35 & Moderate & 0,09 & Low & 0,60 & Moderate & 4,28 & Low \\
\hline Sariwani & 0,44 & Low & 0,29 & Low & 0,24 & Low & 0,13 & Low & 0,41 & Moderate & 3,33 & Low \\
\hline Sukapura & 0,61 & Moderate & 0,20 & Low & 0,15 & Low & 0,33 & Low & 0,92 & High & 11,99 & Moderate \\
\hline Wonokerto & 0,38 & Low & 0,26 & Low & 0,59 & High & 0,34 & Low & 0,38 & Low & 4,28 & Low \\
\hline Wonotoro & 0,93 & High & 0,38 & $\begin{array}{c}\text { Modera } \\
\text { te }\end{array}$ & 0,15 & Moderate & 0,98 & High & 0,13 & Low & 8,08 & Moderate \\
\hline
\end{tabular}

1. Ngadas Village, despite the high hazard area from the eruption of Mount Bromo, has a moderate level risk. However, the lowhazard village of Sukapura has a high risk. It shows that the most influential factor on the magnitude of the risk is not only the hazard of the disaster itself but the existence of vulnerability and capacity factor that has a greater impact on the community. Therefore, high-risk areas in Sukapura District need to reduce the level of vulnerability and increase the capacity of the community.

Table 9. Bromo Mountain Eruption Risk Area In Villages In Sukpura District

\begin{tabular}{|c|c|c|c|c|}
\hline \multirow{2}{*}{ Villages } & \multicolumn{4}{|c|}{ Disaster Risk Area (ha) } \\
\cline { 2 - 5 } & Low & Moderate & High & $\begin{array}{c}\text { No } \\
\text { Risk }\end{array}$ \\
\hline Ngadisari & - & - & 1036,39 & - \\
\hline Sariwani & - & - & 2339,22 & - \\
\hline Kedasih & - & 894,87 & - & 89,38 \\
\hline Pakel & - & 608,37 & - & 4,04 \\
\hline Ngepung & 443,86 & - & - & 252,52 \\
\hline Sukapura & 807,99 & - & - & - \\
\hline Sapikerep & - & - & 1328,31 & - \\
\hline Wonokerto & - & - & 486,93 & - \\
\hline Ngadirejo & - & - & 1485,98 & - \\
\hline Ngadas & 144,70 & 971,24 & - & - \\
\hline Jetak & - & 144,08 & 122,72 & - \\
\hline Wonotoro & 233,85 & 159,13 & - & - \\
\hline Total & $\mathbf{1 6 3 0 , 4}$ & $\mathbf{2 7 7 7 , 6 9}$ & $\mathbf{6 7 9 9 , 5 5}$ & $\mathbf{3 4 5 , 9 4}$ \\
\hline
\end{tabular}

2. Community capacity enhancement efforts in Sukapura District have been conducted by the central and regional government, and the communities themselves. The government, through BPBD Probolinggo Regency, has compiled a Contingency Plan for Mount Bromo Eruption, determines the evacuation point and conducts the evacuation drill when an eruption occurs, gives counseling and so on. There is also community incorporated in the Bromo Lover organization, a DRR forum.

3. Decreasing the level of vulnerability is not as easy as improving the capacity of the community because the vulnerability is not only attached to individuals or groups but is rooted in complex social processes and relationships. As explained at the beginning, Mount Bromo and Tenger people are of two inseparable entities, on the one hand, it can reduce the vulnerability, but on the other it increases the vulnerability, for instance: 1) Tengger people consider the eruption of Mount Bromo is a blessing to be thankful for, but the government considers the eruption of Mount Bromo as a hazard; 2) living around Mount Bromo on one side brings economic benefits such as fertile soils and potential to be developed as natural attractions, but on the other hand it can endanger the property and community; 3 ) The existence of traditional chairman, on the one hand, is an important government agency in informing government programs in DRR but on the other hand it can hinder the evacuation process because of his belief that the eruption of Mount Bromo is a blessing to be grateful and greeted with joy.

\section{Conclusion}

Based on the disaster risk analysis, the level of disaster risk in Sukapura District can be drawn as follows.

1. High-risk areas cover Ngadisari Village, Sariwani, Sapikerep, Wonokerto, Ngadirejo, and part of Jetak Village.

2. Moderate risk areas include part of Kedasih Village, part of Pakel Village, part of Ngadas Village, part of Jetak Village and part of Wonokerto Village. 
3. Low-risk areas include part of Ngepung Village, Sukapura Village, part of Ngadas Village and part of Wonotoro Village.

Ngadisari Village is the main tourism entrance in Sukapura District. It's also the traditional chairman lives. Therefore Ngadisari village is good for the center of disaster risk reduction efforts in Sukapura District because the village is high-risk areas, the center of tourism activities and the center of cultural activities of the Tengger Tribe.

We would like to thank the Ministry of Research, Technology and Higher Education (Kemenristek-Dikti) of the Republic of Indonesia which has provided research grants (Superior Research 2017-2018). We also thank the Regional Disaster Management Agency of Probolinggo Regency, Sukapura District Government and all OPD Probolinggo Regency, so the research can be done excellently.

\section{Reference}

1. ESDM. 2014. Data Dasar Gunung Api. [pdf]. (http://www.vsi.esdm.go.id/index.php/gunungapi/ data-dasar-gunungapi, (accessed on 10 September 2017)

2. BPBD Kabupaten Probolinggo. 2016. Dampak Erupsi Gunung Bromo, http://bpbd.probolinggokab.go.id/en/berita/index/ $\underline{68}$ (accessed on 10 September 2017)

3. United Nation International Strategy for Disaster Reduction (UNISDR). Terminology: Basic Terms of Disaster Risk Reduction. UNISDR: Geneva. (2004)

4. Torry WI. Bureaucracy, community and natural disasters. Human Organization 37(3): 302-307. (1978)

5. Torry WI. Anthropological studies in hazardous environments: past trends and new horizons. Current Anthropology. 20(3):517-540. (1979)

6. Hewitt K. (ed). Interpretations of Calamity from the Viewpoint of Human Ecology. Allen \& Unwin: London. (1983)

7. Lewis J. Development in Disaster-prone Places: Studies of Vulnerability. Intermediate Technology Publications: London. (1999)

8. Wisner B, Blaikie P, Connon T, Davis I. At Risk: Natural Hazards, People's Vulnerability, and Disasters. (2 ${ }^{\text {nd }}$ ed). Routledge: London. (2004)

9. Gaillard JC, Liamzon C, Villanueva JD. 'Natural disaster? A retrospect into the causes of the late2004 typhoon disaster in Eastern Luzon, Philippines. Environmental Hazards. 7(4): 257270. (2007)

10. Tran P, Shaw R. Towards an integrated approach of disaster and environmental management: a case study of Thua Thien Hue province in Central Vietnam. Environmental Hazards. 7(4): 271-282. (2007)

11. Mercer J. Disaster Risk Reduction or Climate Change Adaptation: Are We Reinventing the
Wheel?. Journal of International Development. 22: 247-264. (2010)

12. Benson, Charlotte \& Twigg, John. Tools for Mainstreaming Disaster Risk Reduction: Guidance Notes for Development Organisations. ProVention Consortium Secretariat: Switzerland. (2007)

13. Gunadi, Briandana J.A; Nugraha, Arief L \& Suprayogi, Andri. Multi-Risk Disaster Mapping Application in Banyumas District Using Open Source Software GIS. Jurnal Geodesi Undip. 4(4): 287-296. (2015)

14. Sumekto, Didik RinanDisaster Risk Reduction Through Analysis of Community Vulnerability and Capacity in Facing Disasters. Presented at the National Seminar: Merapi Area Development: Aspects of Disaster and PostDisaster Community Development. Hal. 28-38. (2011)

15. Serrat, Oliver. Knowledge Solution: Tools, Methods, and Approaches to Drive Organizational Performance. Mandaluyong, Philippines: Springer Nature. (2017)

16. Kim, Hyun \& Marcouiller, David W. Natural Disaster Response, Community Resilience, and Economic Capacity: A Case Study of Coastal Florida. Society and Natural Resource. 10 (1): 117. (2015)

17. Pelling, M \& C. High. Understanding Adaptation: What Can Social Capital Offer Assessments of Adaptive Capacity. Global Environmental Change 15: 308-319. (2005)

18. Sudibyakto \& Priadmodjo, Anggit. Disaster Risk Management in Gunung Padang Cultural Heritage Area, Ciamis, West Java. Indonesian Disaster Research Journal.2(1): 50-58. (2016). 